\title{
The influence of levodopa on respiratory function in Parkinson's disease patients: a
}

\section{systematic review and meta-analysis}

\author{
A influência da levodopa na função respiratória em pacientes com doença de Parkinson: uma \\ revisão sistemática e meta-análise
}
La influencia de la levodopa en la función respiratoria en pacientes con enfermedad de Parkinson: revisión sistemática y metanálisis

Francisco José Silva Ferreira

ORCID: https://orcid.org/0000-0002-0798-1601 Federal University of Sergipe, Brazil

E-mail: francisco.1942@ hotmail.com

Paulo Eduardo Gonçalves

ORCID: https://orcid.org/0000-0002-9433-6482

Federal University of Sergipe, Brazil

E-mail: pauloeduptc@hotmail.com

Alice Santos Lima

ORCID: https://orcid.org/0000-0002-3412-5165 Federal University of Sergipe, Brazil E-mail: alicefla2010@hotmail.com

Diogo Costa Garção

ORCID: https://orcid.org/0000-0001-9456-6563 Federal University of Sergipe, Brazil E-mail: diogoufscar@yahoo.com.br

\begin{abstract}
There is no consensus in the literature about the influence of levodopa on respiratory disorders, which are the main cause of death in Parkinson's disease patients. Thus, the aim of this study was to conduct a systematic review and meta-analysis to assess the influence of levodopa on lung function in patients with Parkinson's disease. A systematic search was performed in the MEDLINE-PubMed, Lilacs, IEEE Xplore Digital Library and Cochrane Library databases, until July 2020. Eligibility, screening, data extraction and quality assessment of the studies found were conducted independently by a minimum of two reviewers. The meta-analysis was made using RevMan 5, using standardized difference of means (SDM) with the random effects model and $95 \%$ confidence interval. The presence of heterogeneity was evaluated through the percentage of $i^{2}$. In total, 78 studies were identified; of these, 7 were included in the review and meta-analysis after considering the inclusion and exclusion criteria. By comparing the 'on' and 'off' levodopa states, in the outcomes of interest found in the included studies, the following results were obtained in the meta-analysis: FVC (SMD of 0.12, p = 0.41); FEV $($ SMD of 0.10, p = 0.47); PEF (SMD of -0.00, p = 0.99); $\mathrm{FEV}_{1} / \mathrm{FVC}$ (SMD 0.04, $\mathrm{p}=0.76$ ). The conducted study suggested that there was no influence of levodopa treatment on any of the pulmonary variables assessed in patients with Parkinson's disease.

Keywords: Parkinson disease; Levodopa; Vital capacity; Total lung capacity; Lung volume measurements; Tidal volume.

\section{Resumo}

Não existe um consenso na literatura sobre a influência da levodopa sobre as disfunções respiratórias, que são a principal causa de morte em pacientes com doença de Parkinson. Assim, o objetivo desse estudo foi conduzir uma revisão sistemática e meta-análise para avaliar qual a influência da levodopa na função pulmonar em pacientes com doença de Parkinson. Foi realizada uma procura sistemática nos bancos de dados MEDLINE-PubMed, Lilacs, IEEE Xplore Digital Library e Cochrane Library, até julho de 2020. Elegibilidade, triagem, extração de dados e avaliação de qualidade dos estudos encontrados foram conduzidas independentemente por um mínimo de dois revisores. A metaanálise foi então conduzida através do RevMan 5, utilizando diferença padronizada de médias com o modelo de efeitos aleatórios e intervalo de confiança de $95 \%$. A presença de heterogeneidade foi avaliada através do percentual de $\mathrm{i}^{2}$. No total, 78 estudos foram identificados; destes, 7 foram incluídos na revisão e meta-análise depois de considerados os critérios de inclusão e exclusão. Através do confrontamento dos estados " on " e “off”' levodopa, nos desfechos de interesse encontradas nos estudos incluídos, foram obtidos os seguintes resultados na meta-análise: FVC $(\mathrm{SMD}$ de 0.12, $p=0.41) ; \mathrm{FEV}_{1}(\mathrm{SMD}$ de 0.10, $p=0.47)$; PEF (SMD de -0.00, $\left.p=0.99\right) ; \mathrm{FEV}_{1} / \mathrm{FVC}$ (SMD de 0.04, $p$
\end{abstract}


= 0.76). O estudo conduzido sugeriu não haver influência do tratamento com levodopa em quaisquer das variáveis pulmonares avaliadas em pacientes com doença de Parkinson.

Palavras-chave: Doença de Parkinson; Levodopa; Capacidade vital; Capacidade pulmonar total, Medidas de volume pulmonar; Volume de ventilação pulmonar.

\begin{abstract}
Resumen
No existe consenso en la literatura sobre la influencia de la levodopa en los trastornos respiratorios, que son la principal causa de muerte en pacientes con enfermedad de Parkinson. Por tanto, el objetivo del estudio fue realizar una revisión sistemática y un metanálisis para evaluar el impacto de la levodopa en la función pulmonar en pacientes con enfermedad de Parkinson. Se realizó una búsqueda sistemática en las bases de datos MEDLINE-PubMed, Lilacs, IEEE Xplore Digital Library y Cochrane Library, hasta julio de 2020. La elegibilidad, cribado, extracción de datos y evaluación de la calidad de los estudios encontrados fueron realizados por al menos dos revisores. A continuación, se realizó un metanálisis utilizando RevMan 5, utilizando la diferencia de medias estandarizada con el modelo de efectos aleatorios y el intervalo de confianza del $95 \%$. La presencia de heterogeneidad se evaluó mediante el porcentaje de $\mathrm{i}^{2}$. En total, se identificaron 78 estudios; de estos, 7 se incluyeron en la revisión y metanálisis después de considerar los criterios de inclusión y exclusión. Al comparar los estados de levodopa "on" y "off", en los resultados de interés encontrados en los estudios incluidos, se obtuvieron los siguientes resultados en el metanálisis: FVC (SDM de 0,12, p = 0,41); FEV1 (SDM 0,10, p =0,47); PEF (SDM -0,00, p = 0,99); FEV1 / FVC (SDM 0,04, p = 0,76). El estudio realizado sugirió que no hubo impacto del tratamiento con levodopa en ninguna de las variables pulmonares evaluadas en pacientes con enfermedad de Parkinson.
\end{abstract}

Palabras clave: Enfermedad de Parkinson; Levodopa; Capacidad vital; Capacidad pulmonar total; Mediciones del volumen pulmonar; Volumen de ventilación pulmonar.

\title{
1. Introduction
}

Parkinson's disease (PD) is a progressive neurodegenerative disorder that mainly affects the elderly population over 60 years of age. Respiratory dysfunctions were first described and associated with Parkinson's disease in 1817 (Parkinson, 1817), and remain until today as the main cause of death on these patients (Bogaard et al., 1989). Since its discovery in the 1960s, levodopa has been considered the gold standard treatment for patients with Parkinson's disease (Cotzias, 1968), but its effect on respiratory function remains unclear.

PD has its pathophysiology directly related to the degeneration of dopaminergic neurons in the substantia nigra of the midbrain, which leads to dysfunctions in the circuitry of the basal ganglia (Kalia \& Lang, 2016). Although a small minority of these patients had a monogenetic etiology for the problem, whether recessive or dominant, the vast majority had a sporadic etiology or of unknown cause (Deng et al., 2018).

The clinical condition of PD is usually characterized by the classic presence of a triad with rigidity, tremor and bradykinesia, although there are also non-motor symptoms. Many patterns of respiratory dysfunction have been described in PD, including restrictive changes secondary to chest wall rigidity and reduced lung volumes, upper airway obstruction, abnormal ventilatory control, diaphragmatic dyskinesia, pleuropulmonary complications from medication, and shortness of breath (Torsney \& Forsyth, 2017). Most patients, however, remain asymptomatic even with grossly abnormal lung tests (Hovestadt, 1989).

Previous studies that analyzed the impact of levodopa on the respiratory function of patients with PD reached controversial results, especially in relation to the variation in lung volume measurements. It seems to be a consensus among the studies only on the lack of significance of the effect of levodopa on the results of $\mathrm{FEV}_{1} / \mathrm{FVC}$ ratio in "on" patients compared to patients in "off" levodopa status (LeWitt et al., 2018; Tambasco et al., 2018; Herer et al., 2001; Weiner et al., 2002; Lim et al., 2008; Sathyaprabha et al., 2005; Pal et al., 2007). In general, such controversies make it difficult to really understand the real efficacy of levodopa in obstructive or restrictive phenomena that can be evidenced through spirometry in these patients with PD.

Therefore, there are gaps that need further clarification. Thus, this systematic review and meta-analysis will aim to assess the influence of levodopa treatment on lung function in patients with PD. 


\section{Methods}

This study was conducted in accordance with the Preferred Reporting Items for Systematic Reviews and MetaAnalysea (PRISMA) (Moher et al., 2009) statement, supplemented by guidelines from the Cochrane Collaboration Handbook, version 6.1 (Higgins et al., 2019). Initially, a protocol for this systematic review was designed and registered in the database PROSPERO data (Registration No. CRD42020200625). The elaboration of the research question was carried out with the PICO monogram. This strategy was used to enable resolution of the survey question and to optimize evidence retrieval from databases.

The following question was raised: what is the influence of levodopa on respiratory changes in patients with Parkinson's disease? Following criteria, P, Parkinson's disease patients, I, levodopa treatment, C, no comparison, O, respiratory changes.

\section{Search strategy}

Four online databases were used to search for material in accordance to the study criteria: National Library of Medicine (MEDLINE-PubMED), Lilacs, IEEE Xplore Digital Library and Cochrane Library. The following keywords were used in combination: 'Parkinson's disease', 'levodopa', 'vital capacity', 'total lung capacity', 'respiratory function tests', 'lung volume measurements' and 'ventilation volume' pulmonary'.

\section{Study selection}

The online search for titles, abstracts and full text of articles was independently reviewed by a minimum of two reviewers. Disagreements about inclusion/exclusion were resolved by consensus. The following inclusion criteria were applied: studies that evaluated variables of forced vital capacity (FVC), forced expiratory volume in one second (FEV $)_{1}$, relationship between $\mathrm{FEV}_{1} / \mathrm{FVC}$ and/or maximum expiratory flow (PEF) in treatment with levodopa in patients with PD. Studies were excluded following the exclusion criteria: individuals with parkinsonism-plus, intervention by other pharmacological treatments, surgical treatment, review articles, meta-analyses, abstracts, conference procedures, editorials/letters and case reports.

\section{Data extraction}

Data were extracted by one reviewer using standardized forms and verified by a second reviewer. The information extracted included the type of study, number of participants, age and Hoehn and Yahr (H\&Y) scale of the participants, time since disease diagnosis, lung volume measurements (FVC, L; FEV $1, \mathrm{~L} ; \mathrm{PEF}, \mathrm{L} / \mathrm{s}$ and $\mathrm{FEV}_{1} \% / \mathrm{FVC} \%$ ), instrument used, dose of levodopa used, route of pharmacological administration, result and conclusion.

\section{Quality evaluation}

Three tools, suggested by the Cochrane Handbook, were used to analyze the quality of the studies selected for this review. For randomized studies, the second version of the Revised Cochrane risk of bias tool for randomized trials (ROB2 tool) (Sterne et al., 2019) was used. In case-control and cohort studies, the tool used was The Newcastle-Ottawa Scale (NOS) for assessing the quality of nonrandomized studies in meta-analyses (Wells et al., 2000). For the cross-sectional studies, the Joanna Briggs Institute's Checklist for Analytical Cross Sectional Studies was used (Moola et al., 2020). The graphs elaborated on the quality of the randomized studies were made using the Robvis visualization tool (McGuinnes \& Higgins, 2020). Two researchers (ASL and PEG) evaluated the studies according to the manual of each tool and disagreements were decided by consensus between them. 


\section{Statistical analysis}

The meta-analysis was conducted using RevMan 5 available for Windows® platform (Cochrane, 2020). The random effects model was used to calculate the forest graphics. The presence of heterogeneity between studies was measured through visual inspection of the graphics and through the percentage of $\mathrm{I}^{2}$. To measure the effects, the variables of interest were used in the standardized mean difference test with a $95 \%$ confidence interval. Thus, $\mathrm{p}<0.05$ was considered significant.

\section{Results}

\section{Study Selection}

The databases search resulted in 78 studies. Of these, 54 were excluded from the screening because they were case reports, reviews, duplicate studies or because they were not clinical trials, in addition to those that did not present the outcome of interest. After reading the full text, another 17 studies were excluded for not meeting the eligibility criteria. Thus, 7 studies were included in the systematic review and meta-analysis (Figure 1).

Figure 1. Flow Diagram for literature searching and screening.

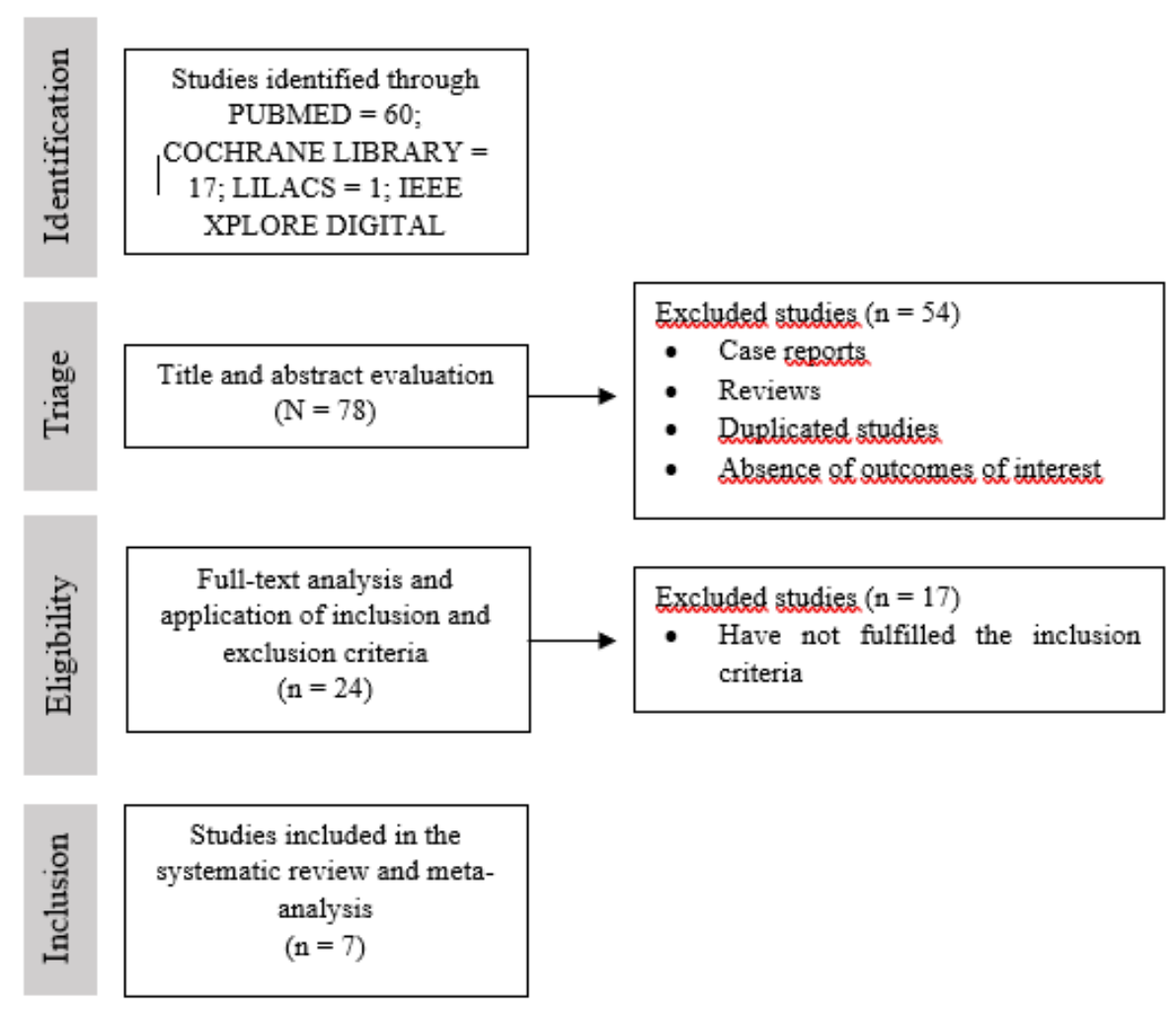

Source: Authors.

\section{Quality Assessment}

Randomized studies (Herer et al. and LeWitt et al.) showed a low risk of bias in the five domains, except for one domain dealing with participant randomization in LeWitt et al. In case-control and cohort studies, Weiner et al., Sathyaprabha et al., Pal et al. and Tambasco et al. obtained 7, 8, 7 and 6 stars, respectively, out of a maximum score of 9 points given by the tool. In the cross-sectional study, Lim et al. left the description of the participants and the identification of confounding factors unclear. 


\section{Characteristics of participants}

By analyzing the demographic characteristics of the patients included in the studies, it was possible to observe a greater number of male patients. In addition, the means found for age of participants, time since diagnosis of the disease and for the Hoehn and Yahr scale were 62.5, 6.3 and 2.4, respectively (Table 1).

Table 1. Demographic characteristics of patients included in the studies.

\begin{tabular}{|c|c|c|c|c|}
\hline Study, Year & $\begin{array}{c}\text { Gender } \\
\text { (Male/Female) }\end{array}$ & $\begin{array}{c}\text { Age, } y \\
\text { (Mean }[\mathrm{SD}] \text { ) }\end{array}$ & $\begin{array}{l}\text { Time since diagnosis, y } \\
\text { (Mean }[\mathrm{SD}])\end{array}$ & $\begin{array}{l}\mathrm{H} \& \mathrm{Y} \\
\text { (Mean) }\end{array}$ \\
\hline Herer et al, 2001 & $11 / 5$ & $77.3(10.1)$ & $5.8(3.6)$ & 2.56 \\
\hline Weiner et al, 2002 & $10 / 10$ & $66.2(2.2)$ & $7.5(1.1)$ & 2.6 \\
\hline Sathyaprabha et al, 2005 & NA (35 total) & $53.0(10)$ & $3.0(2)$ & 2.1 \\
\hline Pal et al, 2007 & $38 / 15$ & $52.6(7.7)$ & $3.1(3.3)$ & NA \\
\hline Lim et al, 2008 & $6 / 4$ & 63.5 & 8.5 & 2.4 \\
\hline Tambasco et al, 2018 & $26 / 8$ & $63.3(11.3)$ & $5.7(3.4)$ & 2.4 \\
\hline LeWitt et al, 2018 & $19 / 5$ & $61.3(7.4)$ & $10.5(4.6)$ & NA \\
\hline
\end{tabular}

\section{Source: Authors.}

\section{Characteristics of the studies}

For the characteristics of the studies included in the meta-analysis, it was observed that out of a total of 7 studies, 2 were double-blind clinical trials and 5 were open-label clinical trials ( 3 of them with a control group), totaling 192 patients. Only one trial used the inhaled route of administration for pharmacological treatment, while the other six used the oral route of administration. In addition, the mean dose in milligrams of levodopa used daily per patient was 703.6 for the inhaled route and 500.6 for the oral route. Among the 7 trials, 5 presented the $\mathrm{FVC}$ and $\mathrm{FEV}_{1}$ outcomes in liters, 3 presented the $\mathrm{FEV}_{1} / \mathrm{FVC}$ outcome in predictive percentage and only 2 presented the PEF outcome in liters per second (Table 2). 
Table 2. Characteristics of the studies included in the meta-analysis.

\begin{tabular}{|c|c|c|c|c|c|}
\hline Author, Year & Study design & Participants & $\begin{array}{c}\text { Route of } \\
\text { administration }\end{array}$ & $\begin{array}{c}\text { Levodopa Daily } \\
\text { Dose, mg } \\
\text { (Mean [SD]) }\end{array}$ & Outcomes \\
\hline Herer et al, 2001 & $\begin{array}{l}\text { Double-blinded } \\
\text { crossover trial }\end{array}$ & 16 & Oral & $363.6(195.1)$ & $\begin{array}{l}\mathrm{FVC}(\mathrm{L}) \\
\mathrm{FEV}_{1}(\mathrm{~L})\end{array}$ \\
\hline Weiner et al, 2002 & $\begin{array}{l}\text { Open-label trial with } \\
\text { control group }\end{array}$ & 20 & Oral & $575.0(65)$ & $\begin{array}{l}\mathrm{FVC}(\mathrm{L}) \\
\mathrm{FEV}_{1}(\mathrm{~L})\end{array}$ \\
\hline Sathyaprabha et al, 2005 & $\begin{array}{l}\text { Open-label trial with } \\
\text { control group }\end{array}$ & 35 & Oral & NA & $\begin{array}{l}\mathrm{FEV}_{1} / \mathrm{FVC} \quad(\% \\
\text { predicted })\end{array}$ \\
\hline Pal et al, 2007 & $\begin{array}{l}\text { Open-label trial with } \\
\text { control group }\end{array}$ & 53 & Oral & NA & $\begin{array}{l}\mathrm{FEV}_{1} / \mathrm{FVC} \\
\text { predicted })\end{array}$ \\
\hline Lim et al, 2008 & Open-label trial & 10 & Oral & 480.0 & $\begin{array}{l}\text { FVC (L) } \\
\operatorname{FEV}_{1}(\mathrm{~L}) \\
\operatorname{PEF}(\mathrm{L} / \mathrm{s})\end{array}$ \\
\hline Tambasco et al, 2018 & Open-label trial & 34 & Oral & $584.0(404.48)$ & $\begin{array}{l}\mathrm{FVC}(\mathrm{L}) \\
\mathrm{FEV}_{1}(\mathrm{~L})\end{array}$ \\
\hline LeWitt et al, 2018 & $\begin{array}{l}\text { Double-blinded } \\
\text { crossover trial }\end{array}$ & 24 & Inhaled & $703.6(435.7)$ & $\begin{array}{l}\text { FVC (L) } \\
\mathrm{FEV}_{1}(\mathrm{~L}) \\
\mathrm{PEF}(\mathrm{L} / \mathrm{s}) \\
\mathrm{FEV}_{1} / \mathrm{FVC} \\
\text { predicted) }\end{array}$ \\
\hline
\end{tabular}

$\mathrm{FVC}=$ forced vital capacity $\mathrm{FEV}_{1}=$ forced expiratory volume in 1 second; $\mathrm{PEF}=$ peak expiratory flow.

Source: Authors.

\section{Outcomes}

The analysis of values evaluated in 104 patients found no significant effect difference when comparing the "on" and "off" states of levodopa for the outcomes of FVC (SMD of 0.12, p = 0.41) (Figure 2) and of FEV ${ }_{1}$ in liters $(\mathrm{SMD}$ of $0.10, \mathrm{p}=$

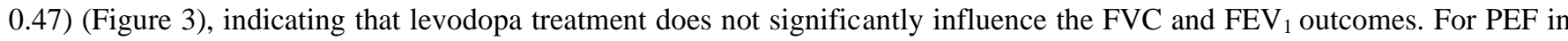
liters per second, there was also no significance when comparing the "on" and "off" states in 26 patients (SMD of 0.00 , p = 0.99) (Figure 4), in addition, for the outcome $\mathrm{FEV}_{1} / \mathrm{FVC}$ in predictive percentage, evaluated in 112 patients, it was also observed that there is no indication of effect significance (SMD of 0.04, p = 0.76) (Figure 5), demonstrating that there is also no significant influence of levodopa treatment for the PEF and $\mathrm{FEV}_{1} / \mathrm{FVC}$ outcomes. 
Figure 2. Forced vital capacity, in liters, after and before levodopa therapy in patients with Parkinson's disease.

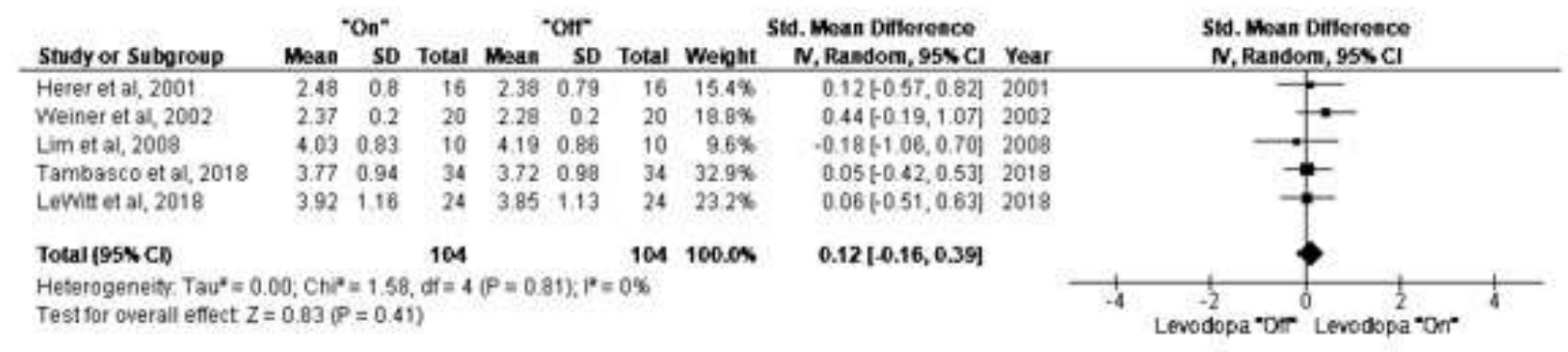

Source: Authors.

Figure 3. Forced expiratory volume in 1 second, in liters, after and before levodopa therapy in patients with Parkinson's disease.

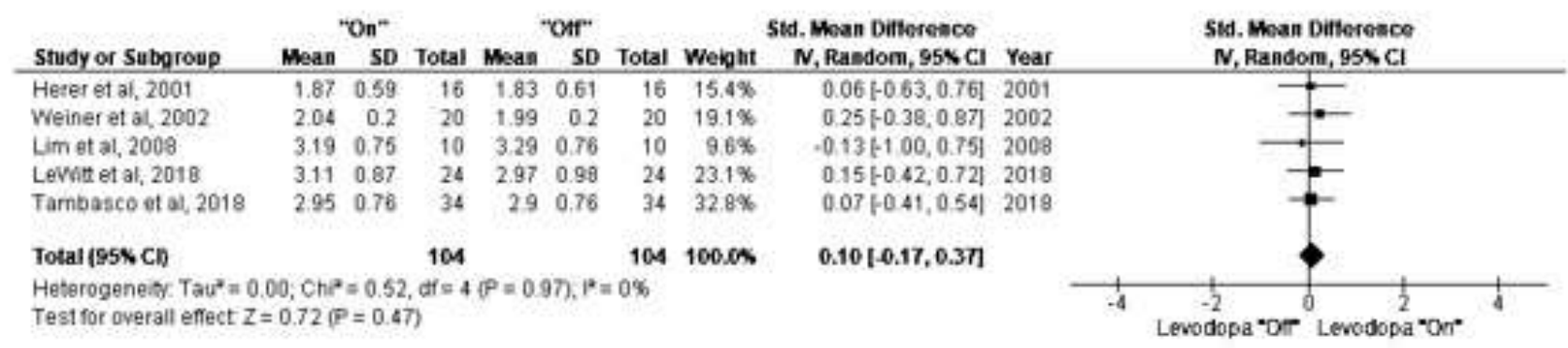

Source: Authors.

Figure 4. Peak expiratory flow, in liters per second, after and before levodopa therapy in patients with Parkinson's disease.

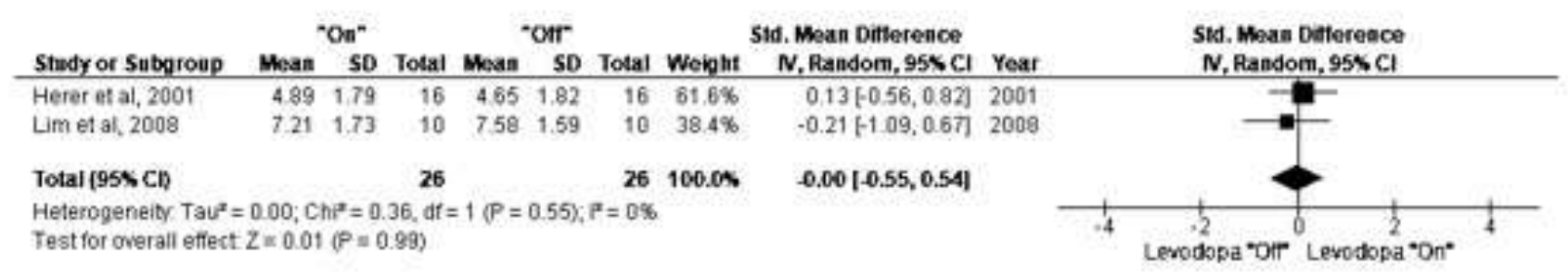

Source: Authors. 
Figure 5. Forced expiratory volume in 1 second, percent predicted (FEV1\%), and forced vital capacity, percent predicted (FVC\%), after and before levodopa therapy in patients with Parkinson's disease.

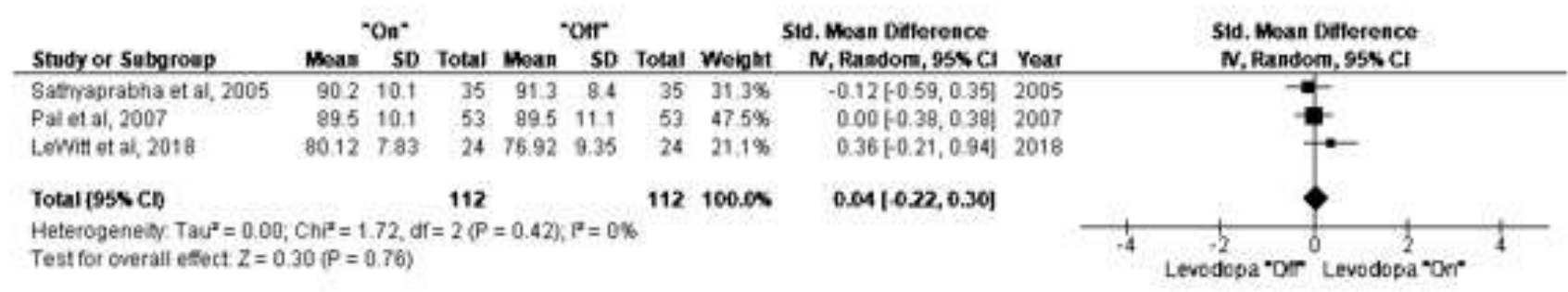

Source: Authors.

\section{Discussion}

Based on the purpose of this systematic review, which was to assess the influence of levodopa on the respiratory function of patients with PD, the present study, through statistical analysis, indicated that there was no statistical significance of effect for the outcomes evaluated when evaluated together. However, most of the studies have shown, in isolation, an improvement in the respiratory parameters evaluated. The values of FVC, FEV $1, \mathrm{PEF}$ and the relationship between $\mathrm{FEV}_{1} / \mathrm{FVC}$ allow us to assess respiratory disorders, whether obstructive, restrictive, obstructive with reduced vital capacity, mixed or combined and nonspecific (Lorenzi, 2005; Duarte et al., 2007; Templeman \& Roberts, 2020).

Forced Vital Capacity (FVC) is the measure of the amount of air that leaves the lungs in a forced exhalation. Its measurement is of great clinical importance for restrictive pulmonary diseases (David \& Sharma, 2019). It also has its use in determining the involvement of respiratory muscles in neuromuscular diseases. In their study with 34 patients, Tambasco et al. demonstrated a significant $(\mathrm{p}=0.026)$ increase in FVC when levodopa was used. On the other hand, Lim et al., in their study with 10 participants, found a significant worsening $(\mathrm{p}=0.002)$ in FVC values after using the medication. Other studies such as LeWitt et al, Herer et al and Weiner et al reached statistically non-significant results regarding the variation in FVC with the use of levodopa.

By definition, the forced exhaled volume in one second $\left(\mathrm{FEV}_{1}\right)$ is the amount of air exhaled by the lungs in the first second (s) of forced expiration, which is performed after a maximum inspiration. This variable is used to assess the severity of obstructive pulmonary diseases. Tambasco et al demonstrated that there was also a significant improvement $(\mathrm{p}=0.001)$ in the $\mathrm{FEV}_{1}$ values. Again, Lim et al. indicated an opposite result, pointing to a significant decline $(\mathrm{p}=0.035)$ in $\mathrm{FEV} \mathrm{V}_{1}$ values after using the medication. Other studies such as LeWitt et al, Herer et al and Weiner et al reached statistically non-significant results regarding the variation in $\mathrm{FEV}_{1}$ with the use of levodopa.

Maximum expiratory flow (PEF) is the measure of airflow in a forced exhalation. Widely used to assess asthma in outpatient clinics, it allows us to interpret its values and suspect obstructive pulmonary dysfunction (DeVrieze et al., 2017). Herer at al., in their study with 21 participants, 5 of them with upper airway obstruction (UAO), suggested that there was mean improvement $(p=0.02)$ in the PEF outcome. Lim et al, on the other hand, suggested the absence of effect significance in their study for the variable PEF.

The ratio between forced expiratory volume in one second and forced vital capacity ( $\left.\mathrm{FEV}_{1} / \mathrm{FVC}\right)$ makes it possible to

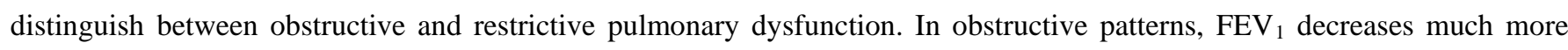
than FVC, so the rate of this relationship is less than 70\%. In restrictive patterns, this rate tends to be greater than $70 \%$ (Lamb et al., 2020; David \& Edwards, 2019). LeWitt et al. and Sathyaprabha et al. did not find statistical significance of changes in 
$\mathrm{FEV}_{1} / \mathrm{FVC}$ values when comparing patients in 'off' and 'on' status. Both studies suggest, however, that PD causes a restrictive pattern of pulmonary dysfunction, which may be associated with muscle rigidity presented in the clinic of patients with PD.

Therefore, it is already known that PD can present with restrictive respiratory alterations. However, it is still extremely necessary for further randomized studies to be carried out on the impact of levodopa on the respiratory function of these patients, since, although being the gold standard treatment for the disease, the real influence of the medication is still unknown on respiratory disorders, which together are the leading cause of death in these patients. It is also necessary, by the authors of studies, that there is a standardization of the results of their spirometric studies, either in liters or in predictive value of normal, since there is a variation that makes difficult to analyze the studies together.

This study is limited, firstly, to the low number of randomized studies available on the subject. In addition, the lack of standardization in the literature of the outcome measurement units present in the studies found limited the possibility of further analysis.

\section{Conclusion}

This systematic review and meta-analysis indicated that there is no significant influence of levodopa treatment on the pulmonary variables evaluated $\left(\mathrm{FEV}_{1}, \mathrm{FVC}, \mathrm{PEF}, \mathrm{FEV}_{1} / \mathrm{FVC}\right)$ in patients with $\mathrm{PD}$.

It is suggested that further primary studies with better standardization of their spirometric variables, either in liters or in predictive value of normal, are needed to clarify the impact of levodopa on respiratory function in patients with PD.

\section{References}

Bogaard, J. M., Hovestadt, A., Meerwaldt, J., V. D., Meché, F. G. A., \& Stigt, J. (1989). Maximal expiratory and inspiratory flow-volume curves in parkinson's disease. American Review of Respiratory Disease, 139(3), 610-614. https://doi.org/10.1164/ajrccm/139.3.610

David, S., \& Edwards, C. W. (2019). Forced expiratory volume.

David, S., \& Sharma, S. (2019). Vital Capacity.

Deng, H., Wang, P., \& Jankovic, J. (2018). The genetics of Parkinson disease. Ageing Research Reviews, 42, 72-85. https://doi.org/10.1016/j.arr.2017.12.007

DeVrieze, B. W., Modi, P., \& Giwa, A. O. (2017). Peak Flow Rate Measurement.

Duarte, A. A. D. O., Pereira, C. A. D. C., \& Rodrigues, S. C. S. (2007). Validation of new brazilian predicted values for forced spirometry in caucasians and comparison with predicted values obtained using other reference equations. Jornal Brasileiro de Pneumologia, 33, 527-535.

Herer, B., Arnulf, I., \& Housset, B. (2001). Effects of levodopa on pulmonary function in parkinson's disease. Chest, 119(2), 387-393. https://doi.org/10.1378/chest.119.2.387

Higgins, J. P., Thomas, J., Chandler, J., Cumpston, M., Li, T., Page, M. J., \& Welch, V. A. (Eds.). (2019). Cochrane handbook for systematic reviews of interventions. John Wiley \& Sons.

Hovestadt, A., Bogaard, J. M., Meerwaldt, J. D., van der Meché, F. G., \& Stigt, J. (1989). Pulmonary function in Parkinson's disease. Journal of Neurology, Neurosurgery, and Psychiatry, 52(3), 329-333. https://doi.org/10.1136/jnnp.52.3.329

Kalia, L. V., \& Lang, A. E. (2016). Evolving basic, pathological and clinical concepts in PD. Nature Reviews Neurology, 12(2), 65-66. https://doi.org/10.1038/nrneurol.2015.249

Lamb, K., Theodore, D., \& Bhutta, B. S. (2020). Spirometry. StatPearls [Internet].

L-dopa for parkinsonism. (1968). New England Journal of Medicine, 278(11), 630-630. https://doi.org/10.1056/NEJM196803142781127

LeWitt, P. A., Pahwa, R., Sedkov, A., Corbin, A., Batycky, R., \& Murck, H. (2018). Pulmonary safety and tolerability of inhaled levodopa (CVT-301) administered to patients with parkinson's disease. Journal of Aerosol Medicine and Pulmonary Drug Delivery, 31(3), 155-161. https://doi.org/10.1089/jamp.2016.1354

Lim, A., Leow, L., Huckabee, M.-L., Frampton, C., \& Anderson, T. (2008). A pilot study of respiration and swallowing integration in parkinson's disease: “On” and “off” levodopa. Dysphagia, 23(1), 76-81. https://doi.org/10.1007/s00455-007-9100-9

Lorenzi, F. G. (2005). II Consenso Brasileiro sobre Doença Pulmonar Obstrutiva Crônica-DPOC. J bras pneumol, 30(5). 
Research, Society and Development, v. 10, n. 14, e457101422262, 2021

(CC BY 4.0) | ISSN 2525-3409 | DOI: http://dx.doi.org/10.33448/rsd-v10i14.22262

McGuinness, L. A., \& Higgins, J. P. T. (2020). Risk-of-bias VISualization (Robvis): An R package and Shiny web app for visualizing risk-of-bias assessments. Research Synthesis Methods, 12(1), 55-61. https://doi.org/10.1002/jrsm.1411

Moher, D., Liberati, A., Tetzlaff, J., Altman, D. G., \& The PRISMA Group. (2009). Preferred reporting items for systematic reviews and meta-analyses: The prisma statement. PLoS Medicine, 6(7), e1000097. https://doi.org/10.1371/journal.pmed.1000097

Moola, S., Munn, Z., Tufanaru, C., Aromataris, E., Sears, K., Sfetc, R., Currie, M., Lisy, K., Qureshi, R., Mattis, P., \& Mu, P.-F. (2020). Chapter 7: Systematic reviews of etiology and risk. In E. Aromataris \& Z. Munn (Orgs.), JBI Manual for Evidence Synthesis. JBI. https://doi.org/10.46658/JBIMES-20-08

Pal, P. K., Sathyaprabha, T. N., Tuhina, P., \& Thennarasu, K. (2007). Pattern of subclinical pulmonary dysfunctions in Parkinson's disease and the effect of levodopa. Movement Disorders, 22(3), 420-424. https://doi.org/10.1002/mds.21330

Parkinson, J. (1817). An essay on the shaking palsey. Sherwood, Neely and Jones.

Review Manager (RevMan) [Computer program]. Version 5.4, The Cochrane Collaboration, 2020.

Sathyaprabha, T. N., Kapavarapu, P. K., Pall, P. K., Thennarasu, K., \& Raju, T. R. (2005). Pulmonary functions in Parkinson's disease. The Indian Journal of Chest Diseases \& Allied Sciences, 47(4), 251-257.

Sterne, J. A. C., Savović, J., Page, M. J., Elbers, R. G., Blencowe, N. S., Boutron, I., Cates, C. J., Cheng, H.-Y., Corbett, M. S., Eldridge, S. M., Emberson, J. R., Hernán, M. A., Hopewell, S., Hróbjartsson, A., Junqueira, D. R., Jüni, P., Kirkham, J. J., Lasserson, T., Li, T., \& Higgins, J. P. T. (2019). RoB 2: A revised tool for assessing risk of bias in randomised trials. BMJ, 14898. https://doi.org/10.1136/bmj.14898

Tambasco, N., Murgia, N., Nigro, P., Paoletti, F. P., Romoli, M., Brahimi, E., Filidei, M., Simoni, S., Muzi, G., \& Calabresi, P. (2018). Levodopa-responsive breathing discomfort in Parkinson's disease patients. Journal of Neural Transmission, 125(7), 1033-1036. https://doi.org/10.1007/s00702-018-1890-4

Templeman, L., \& Roberts, F. (2020). Effectiveness of expiratory muscle strength training on expiratory strength, pulmonary function and cough in the adult population: a systematic review. Physiotherapy, 106, 43-51.

Torsney, K., \& Forsyth, D. (2017). Respiratory dysfunction in Parkinson's disease. Journal of the Royal College of Physicians of Edinburgh, 47(1), 35-39. https://doi.org/10.4997/JRCPE.2017.108

Weiner, P., Inzelberg, R., Davidovich, A., Nisipeanu, P., Magadle, R., Berar-Yanay, N., \& Carasso, R. L. (2002). Respiratory muscle performance and the perception of dyspnea in parkinson's disease. Canadian Journal of Neurological Sciences / Journal Canadien Des Sciences Neurologiques, $29(1)$, 68-72. https://doi.org/10.1017/S031716710000175X

Wells, G. A., Shea, B., O’Connell, D., Peterson, J., Welch, V., Losos, M., \& Tugwell, P. (2000). The Newcastle-Ottawa Scale (NOS) for assessing the quality of nonrandomised studies in meta-analyses. 